\title{
LAICYZACYJNA ROLA REFORMY PRAWA MAŁŻEŃSKIEGO I URZĘDÓW STANU CYWILNEGO W WOJ. BIAŁOSTOCKIM W LATACH 1945-1948
}

Animowana przez komunistyczny reżim ateizacja stosunków społecznych dotykała nie tylko wymiaru publicznego (zachowań w szerszych społecznościach, takich jak: szkoły, miejsca pracy, organizacje masowe), ale również sfery prywatnej, rodzinnej, intymnej. Przy pomocy prawa i strzegącej go administracji starano się zmieniać indywidualne postawy obyczajowe i religijne. W ten nurt centralnie sterowanych przemian kulturowych wpisała się wprowadzona dekretem Tymczasowego Rządu Jedności Narodowej z 25 września 1945 r. reforma prawa małżeńskiego i systemu rejestracji stanu cywilnego. Posunięcie to odcisnęło się jednoznacznie negatywnie na stosunkach „władzy ludowej” z Kościołem katolickim.

Zeświecczenie prawa małżeńskiego i przejęcie przez urzędy stanu cywilnego rejestracji ślubów, urodzeń i zgonów należało - obok sekularyzacji sektora oświatowo-wychowawczego - do najbardziej kontrowersyjnych i najsilniej nagłośnionych elementów laicyzacji życia społecznego w Polsce w latach 1945-1948.

W województwie białostockim, podobnie jak w skali kraju, w pierwszych miesiącach po drugiej wojnie światowej (tak jak w okresie międzywojennym) nie istniał jednolity system rejestracji akt stanu cywilnego, ani nie obowiązywało jednolite prawo małżeńskie. W tej części województwa, która pod zaborami należała do Królestwa Kongresowego (powiaty: augustowski, grajewski, kolneński, łomżyński, suwalski, wysokomazowiecki), w przypadku wyznań: rzymskokatolickiego, ewnagelickiego, prawosławnego i mariawickiego funkcję urzędnika stanu cywilnego sprawowali przełożeni parafii, a akt stanu cywilnego był równocześnie metryką kościelną i zawierał treści określone przepisami kościelnymi. Natomiast ewidencję stanu cywilnego 
osób należących do innych chrześcijańskich oraz niechrześcijańskich związków wyznaniowych prowadzili przełożeni gmin miejskich i wiejskich (urzędnicy świeccy). Na terenach w okresie rozbiorowym wcielonych do Cesarstwa Rosyjskiego (powiaty białostocki, bielski, sokólski) prowadzenie ksiąg metrykalnych należało do kompetencji duchowieństwa wyznań prawnie uznanych, a członkowie małych liczebnie związków wyznaniowych podlegali rejestracji w powiatach. Z kolei na Ziemiach Odzyskanych (powiat ełcki, gołdapski, olecki) obowiązywała wprowadzona tam ustawą z 6 lutego 1878 r. rejestracja świecka ${ }^{1}$.

Rozkład terytorialny różnych przepisów prawa małżeńskiego był w województwie białostockim podobnie zróżnicowany. Na terenach należących w przeszłości do Królestwa Kongresowego przepisy (wprowadzone nakazem cara Mikołaja I z 16 marca 1836 r. wraz z późniejszymi modyfikacjami) uznawały wyłącznie religijną formę zawierania małżeństwa. Jurysdykcja w sprawach małżeńskich (orzekanie ważności lub nieważności, separacji lub rozwiązania małżeństwa) w przypadku wyznań: rzymskokatolickiego, prawosławnego, unickiego i ewangelickich (augsburskiego i reformowanego) należała do sądów konsystorskich (duchownych), natomiast osoby innych wyznań i religii podlegały sądom państwowym. Istniały też odrębne przepisy odnośnie małżeństw mieszanych. Na terenach wcielonych dawniej do Rosji stosowano stare rosyjskie prawo małżeńskie (z 1832 i 1864 r.), regulujące kwestie małżeńskie odrębnie dla każdego uznanego wyznania zgodnie $z$ normami tegoż wyznania. Natomiast na Ziemiach Odzyskanych obowiązywało świeckie prawo małżeńskie (kodeks cywilny Rzeszy Niemieckiej), uznające tylko śluby cywilne - ślub religijny nie miał znaczenia prawnego i wolno go było zawrzeć dopiero po zawarciu związku przed urzędnikiem stanu cywilnego. Sprawy małżeńskie rozstrzygały wyłącznie sądy państwowe, a rozwody były dopuszczone dla wszystkich wyznan ${ }^{2}$.

„Władza ludowa”, dążąc do zdobycia wpływu na wszystkie sfery życia publicznego, zamierzała pod pozorem ujednolicenia przepisów prawa przejać pełną kontrolę nad rejestracją urodzeń, ślubów i zgonów oraz narzucić społeczeństwu (w większości katolickiemu) ateistyczny model małżeństwa. Plany rządu odnośnie reformy prawa małżeńskiego spotkały się ze zdecydowanym sprzeciwem Episkopatu Polski, wyrażonym w piśmie protestacyjnym z 27 czerwca 1945 r., złożonym na ręce prezydenta Krajowej Rady Narodowej

1 J. F. Godlewski, K. H. Jabłoński, Prawo a religia, Warszawa 1988, s. 67-68.

2 Ibidem, s. 70-72. 
Bolesława Bieruta: „Kościół na to zgodzić się nie może, by władza świecka miała określać, co należy do istoty i ważności węzła małżeńskiego katolików. Przymusowe śluby cywilne są dla katolików nie do przyjęcia, gdyż albo zaprzeczają wprost ważności małżeństwa zawartego w Kościele, albo stawiają na równi sakrament małżeństwa $z$ ugodą małżeńską, wyrażoną wyłącznie przed urzędnikiem świeckim. Nowa ustawa małżeńska powinna również uniknąć, groźnego i dla Państwa i Kościoła, niebezpieczeństwa rozwodów" 3.

Władze, nie licząc się ze zdaniem Kościoła, już latem 1945 r. rozpoczęły kampanię propagandową przygotowu jącą grunt pod projektowaną reformę. W połowie lipca 1945 r. organ Wojewódzkiego Urzędu Informacji i Propagandy w Białymstoku („Jedność Narodowa”) opublikował streszczenie odpowiedzi ministra sprawiedliwości na cytowany list protestacyjny biskupów polskich z czerwca. Z tej ogólnikowej relacji prasowej wynikało, iż rząd jest zdeterminowany $\mathrm{w}$ zamiarze wprowadzenia instytucji obligatoryjnych ślubów cywilnych i monopolu świeckich urzędów stanu cywilnego w jak najbliższym czasie ${ }^{4}$.

Kilka tygodni później (w połowie sierpnia) „Jedność Narodowa” nagłośniła uchwałę krajowego zjazdu prezesów i prokuratorów sądów apelacyjnych oraz sądów specjalnych, solidaryzującą się z zasadami projektu prawa małżeńskiego i uznającą konieczność pilnego wprowadzenia tego projektu w życie ${ }^{5}$. W publikacji białostockiej gazety zastosowano szereg chwytów propagandowych: a) zamiast zapoznać czytelników z zasadami projektowanego prawa, budowano poparcie dla ogólnikowego hasła wywoławczego „świeckie prawo małżeńskie”; b) przedstawiono jedynie pochlebne (i bardzo ogólnikowe) opinie na temat reformy, pomijając argumenty przeciwników zmian; c) prawników pokazano (już w tytule) jako środowisko autorytatywne w sprawach moralnych; d) w argumentacji, pomijając wymiar etyczny problemu, akcentowano aspekt prawny (wspominano o konieczności opanowania chaosu prawnego, unifikacji prawa); e) ukazując świeckie prawo małżeńskie jako część (wręcz probierz) „dorobku kultury prawnej suwerennych państw cywilizowanych" - sugerowano między wierszami, że dzięki laicyzacji

3 Pismo protestacyjne Konferencji Episkopatu Polski na Jasnej Górze z 27 czerwca 1945 r. do prezydenta KRN Bolesława Bieruta, w: P. Raina, Kościót w PRL. Kościót katolicki a państwo w świetle dokumentów 1945-1989, t. 1 (lata 1945-1959), Poznań 1994, s. $12-13$.

4 Śluby cywilne, „Jedność Narodowa” nr 31, 18 lipca 1945, s. 3.

5 Prawnicy o ślubach cywilnych, „Jedność Narodowa” nr 38, 12-14 sierpnia 1945, s. 5. Zjazd odbył się w dniach 29 i 30 lipca 1945 r. w Warszawie. 
instytucji małżeństwa Polska stanie się bardziej cywilizowana (i udowodni swą suwerenność).

W tym samym numerze „Jedności Narodowej” ogłoszono ankietę w sprawie reformy małżeńskiego prawa, na którą składały się trzy tendencyjnie dobrane pytania:

„1) Czy obywatelowi Rplitej Polskiej winno przysługiwać prawo ślubu cywilnego?

2) Czy postulat nierozerwalności małżeństwa jest zgodny z zasadami etyki społecznej?

3) Jakie hamulce prawne sa potrzebne przeciw zbyt łatwym rozwodom przy zmianie prawa małżeńskiego?" 6

Pierwsze dwa pytania, odwołując się do egoizmu i zachęcając czytelników do przy jęcia postawy roszczeniowej, skłaniały do udzielenia pozytywnej odpowiedzi. Pytanie trzecie, zakładając z góry wprowadzenie rozwodów, podsuwało odpowiedź twierdzącą na pytania poprzedzające. W pierwszym z pytań wartościowano śluby cywilne jednoznacznie pozytywnie, przedstawiając je jako uprawnienie, a nie obowiązek. W drugim pytaniu wprowadzono wątpliwość co do godziwości nierozerwalności małżeństwa oraz posłużono się kategorią „etyki społecznej” w taki sposób, jakby istniała uniwersalna etyka uznawana przez wszystkich albo trwałość małżeństwa była jednakowo traktowana przez wszystkie systemy etyczne.

Niebawem pojawiły się odpowiedzi na ankietę i to nie byle kogo, bo wyłącznie najwyższych przedstawicieli elity rządzącej w województwie, m.in. przewodniczącego Wojewódzkiej Rady Narodowej, Witolda Wenclika i prezydenta Białegostoku, Andrzeja Krzewniaka. Wszystkie wypowiedzi jednoznacznie optowały za wprowadzeniem cywilnych ślubów oraz rozwodów i miały wyraźnie agitacyjny charakter. Przewodniczący WRN odwoływał się do „Wielkiej Rewolucji Francuskiej” i kodeksu Napoleona, biadał nad niemoralnością utrzymywania nieudanych małżeństw i zdobył się nawet na refleksję pseudofilozoficzną: „Postulat nierozerwalności małżeństwa byłby etycznym, gdyby społeczeństwo składało się z aniołów" 7 . Wypowiedź przewodniczącego była zgrabna ale absurdalna, bo jakże można uznać zasadę etyki katolickiej (czy jakiejkolwiek innej) za nieetyczną?! Prezydent Białegostoku, uzasadniając przydatność ślubów cywilnych i rozwodów, argumento-

6 Ankieta w sprawie prawa matzeńskiego, „Jedność Narodowa” nr 38, 12-14 sierpnia 1945 , s. 5.

7 W. Wenclik, Odpowiedź na ankietę w sprawie ślubów cywilnych, „Jedność Narodowa" nr 42, 26-28 sierpnia 1945 , s. 5. 
wał, że tylko „rządy despotyczne, idące po linii interesów Rzymu” nie uznały tych instytucji ${ }^{8}$. Pan prezydent dokonał swoistej wolty, utożsamiając pluralistyczne prawo małżeńskie $\mathrm{z}$ despotyzmem (i jednocześnie uniformizację prawną z odchodzeniem od rozwiązań despotycznych). Inny z „respondentów" na marginesie swojej wypowiedzi popularyzował nawet „związki oparte na wolnej miłości” ${ }^{9}$. Znamienne było, że w „sondażu” nie dopuszczono do głosu żadnego duchownego, ani nawet tzw. zwykłych ludzi. Ankieta, która teoretycznie powinna umożliwić zapoznanie się z poglądami społeczeństwa, posłużyła narzuceniu opinii publicznej punktu widzenia władz na poruszane zagadnienie.

Jeszcze przed uchwaleniem nowego prawa małżeńskiego „Jedność Narodowa” zaatakowała prasę katolicką, zarzucając „Niedzieli” i „Tygodnikowi Powszechnemu" upieranie się przy nierozerwalności małżeństwa! ${ }^{10} \mathrm{~W}$ agitacji za rozwodami propagandziści posuwali się do bardzo emocjonalnych stwierdzeń w rodzaju: „Nie ma na świecie świętości takiego Sakramentu, któryby miał prawo przykuć żołnierza spod Lenino czy Tobruka do kochanki niemieckiego gesta powca. Albo nawet kobietę, która przeniosła cały ciężar lat wojny i okupacji do człowieka wracającego do domu z chorobą weneryczną zamiast ran i odznaczeń" ${ }^{11}$. Anonimowy autor, uznając się za specjalistę od sakramentów i epatu jąc współczuciem dla zdradzonych współmałżonków, zachęcał do przedkładania egoizmu ponad moralne zobowiązania i trwania w postawie nieprzebaczania.

Twierdzenie propagandy reżimowej, że nierozerwalność katolickiego małżeństwa zmusza skłócone pary do wspólnego życia, było rozmijaniem się z prawdą, gdyż funkcjonowała instytucja separacji małżeńskiej (jej istnienie było jednak zazwyczaj przemilczane przez prasę prokomunistyczą). Separacja, zgodnie z zasadami wiary katolickiej, nie pozwalała na ponowne zawarcie małżeństwa, ale ktoś, komu nie odpowiadała doktryna Kościoła katolickiego, mógł go bez przeszkód opuścić. Rządowa propaganda kwestię tę

8 A. Krzewniak, Odpowiedź na ankietę $w$ sprawie ślubów cywilnych, „Jedność Narodowa" nr 47, 13-15 września 1945, s. 2. Krytyka wpływów Watykanu i uzasadnianie planowanej reformy koniecznością ich usunięcia - w kraju zniewolonym przez Związek Radziecki - było nie tylko niedorzeczne, ale i nieprzyzwoite.

9 W. Anchimowicz, Odpowiedź na ankietę $w$ sprawie ślubów cywilnych, „Jedność Narodowa" nr 43, 29 sierpnia - 1 września 1945, s. 3.

10 Np.: M. Warszałłowicz, „Mały Dziennik” zmartwychwstat, „Jedność Narodowa” nr 41, 23-25 sierpnia 1945, s. 3.

11 Tygodnik Powszechny „na trzeźwo o matzeństwie”, „Jedność Narodowa” nr 44, 2-5 września 1945 , s. 6 . 
sprowadzała do absurdu. Argumentowano, iż wprowadzenie rozwodów położy kres gorszącym praktykom zmieniania wyznania lub religii w celu rozwiązania małżeństwa, pomijając jednocześnie fakt, że rozwody za początku ją jeszcze bardziej gorszące praktyki publicznego lekceważenia zasad wiary i częstego zmieniania małżonków ${ }^{12}$. Poważną manipulacją było sugerowanie, że rozwody umożliwiłyby katolikom ponowne zawieranie małżeństwa; rozwiązanie związku sakramentalnego przez sąd państwowy w oczach Kościoła było nieważne, a zawarcie później ślubu cywilnego według zasad religii było tylko sformalizowaniem cudzołóstwa - osoba, która tak postępowała sama się wykluczała $z$ sakramentalnego życia Kościoła katolickiego.

Świeckie prawo małżeńskie i urzędy stanu cywilnego wprowadzono dekretem z 25 września 1945 r., którego postanowienia miały wejść w życie 1 stycznia 1946 r. ${ }^{13}$ Nowe przepisy, jednolite dla całego państwa, wprowadzały obowiązek zawierania ślubów cywilnych, dopuszczalność rozwodów, zniesienie separacji(!), nieuznawanie przez państwo jurysdykcji sądów kościelnych w sprawach małżeńskich, przejęcie rejestracji urodzeń, ślubów i zgonów przez urzędy stanu cywilnego. Jeszcze przed ogłoszeniem dekretu, w „Jedności Narodowej” ukazał się artykuł insynuu jący, że duchowieństwo katolickie sprzeciwia się ślubom cywilnym nie ze względów natury religijnej, ale „kieszeniowej”, bojąc się utraty wpływów z opłat pobieranych w związku Z udzielaniem sakramentu małżństwa ${ }^{14}$. Anonimowy autor tego tekstu cynicznie i z przekąsem zapewniał, że wprowadzenie urzędów stanu cywilnego nie obniży dochodów książy „niewspółmiernie pokaźnych w stosunku do zarobków innych zawodów", o czym świadczyć miał przykład Wielkopolski, gdzie instytucja ślubów cywilnych istniała od dawna. „Jedność Narodowa” o dekrecie z 25 września poinformowała dopiero w połowie października, a zasady nowego prawa małżenskiego i przepisy o aktach stanu cywilnego przedstawiła w końcu listopada i w grudniu 1945 r. w cyklu artykułów autorstwa Henryka Szahin-Świnarskiego ${ }^{15}$.

Kościół katolicki na laicyzację prawa małżeńskiego zareagował orędziem Episkopatu Polski z 7 grudnia 1945 r., w którym biskupi protestowali przeciwko zaprowadzeniu ślubów cywilnych i rozwodów oraz poddaniu małżeństw katolickich jurysdykcji sądów państwowych. Szczególne wzburzenie episkopatu wzbudził przepis postanawiający, że w ciągu trzech lat od wejścia

12 Patrz: przypis 4.

13 J. F. Godlewski, K. H. Jabłoński, op. cit., s. 69, 73.

14 Paskarstwo w Kościele, „Jedność Narodowa” nr 57, 7-9 października 1945, s. 2.

15 „Jedność Narodowa” 1945, nr 60, 80, 81, 88. 
w życie nowego prawa każde małżeństwo może być rozwiązane sądownie bez podania powodów, pod warunkiem złożenia zgodnego wniosku przez oboje małżonków ${ }^{16}$.

Natomiast 10 grudnia 1945 r. arcybiskup krakowski Adam Stefan Sapieha wydał „w związku z dekretem z dnia 25 września 1945 r. [...] wprowadzającym nowe prawo małżeńskie" zarządzenia "w sprawie postępowania duszpasterzy i prowadzenia ksiąg parafialnych", które dotarły także do Kurii Metropolitalnej Wileńskiej w Białymstoku. Ze względu na osobisty autorytet arcybiskupa Sapiehy znaczenie jego pouczeń musiało wykraczać poza terytorium metropolii krakowskiej. W dokumencie tym czytamy m.in.: „Dekret wprowadzający nowe prawo małżeńskie zupełnie ignoruje przepisy prawa kościelnego. Wobec tego należy pouczać wiernych, by uprzednio zawierali małżeństwo w kościele a dopiero po zawarciu tegoż udawali się do urzędnika stanu cywilnego celem dopełnienia aktu cywilnego, który będzie miał dla katolików charakter rejestracji ich małżeństwa. Władz państwowych nie należy uwiadamiać o zawartem w kościele małżeństwie - ani też przed pobłogosławieniem małżeństwa w kościele żądać dowodu zawarcia małżeństwa przed urzędnikiem stanu cywilnego. Należy jednak nupturientom zwrócić uwagę na konieczność rejestrowania małżeństwa wobec urzędnika stanu cywilnego ze względu na skutki cywilne takiego zarejestrowania jak np. sprawa emerytury dla żony i dzieci, sprawa dziedziczenia etc." 17

Również duchowieństwo województwa białostockiego opowiedziało się zdecydowanie przeciwko zeświecczeniu instytucji małżeństwa, o czym donosiło sprawozdanie Wojewódzkiego Urzędu Informacji i Propagandy w Białymstoku z końca 1945 r.: „Księża występują przeciwko ślubom cywilnym, nazywają urzędy bezbożnymi" 18 .

Wprowadzanie w życie dekretu z 25 września 1945 r. w województwie białostockim napotykało na szereg przeszkód spowodowanych zbytnim pośpiechem $\mathrm{w}$ forsowaniu reformy i oporem ze strony katolickiego w większości społeczeństwa. Już w grudniu 1945 r. wojewoda białostocki, Stefan Dybowski, w piśmie do starostów powiatowych i prezydenta Białegostoku

16 Orędzie Episkopatu Polski w sprawie małżńskiej z 7 grudnia 1945 r., w: Listy pasterskie Episkopatu Polski 1945-1974, Paryż 1975, s. 25-28.

17 Archiwum Kurii Metropolitalnej Białostockiej (dalej: AKMB), Odpis pisma Księcia Arcybiskupa Krakowskiego Adama Stefana Sapiehy z 10 grudnia 1945 r. wydanego w związku z dekretem z dnia 25 września 1945 r. wprowadzającym nowe prawo małżeńskie.

18 Archiwum Państwowe w Białymstoku (dalej: APwB), Wojewódzki Urząd Informacji i Propagandy (dalej: WUIiP), syg. 16, Sprawozdanie Wydziału Polityczno-Wychowawczego WUIiP w Białymstoku pt. „Ogólna ocena sytuacji” z końca 1945 r., s. 4. 
zwracał uwagę na trudności, jakie może spowodować słaba znajomość przepisów prawa o aktach stanu cywilnego (szczególnie przepisów wprowadzających) wśród urzędników gminnych: „Nieznajomość tych norm narazić może powagę władz administracji ogólnej a także może spowodować zbędne zadrażnienia $\mathrm{z}$ osobami duchownymi, prowadzącymi dotychczas akta stanu cywilnego" 19 .

Pierwsze miesiące funkcjonowania dekretu u jawniły brak odpowiedniego przygotowania władz lokalnych oraz niechęć ludności i duchowieństwa katolickiego. Dochodziło m.in. do spięć wokół opłat za wyciągi i odpisy z metryk kościelnych sporządzonych przed 1 stycznia $1946 \mathrm{r}$. Przepisy wprowadzające prawo o aktach stanu cywilnego - ze względu na konieczność dostępu do wzmiankowanych dokumentów kościelnych, bez których nowy system ewidencji obejść się nie mógł - zobowiązywały proboszczów do udostępniania wyciągów i odpisów z metryk za pobraniem opłaty nie wyższej niż ustalona w taryfie dla urzędów stanu cywilnego ${ }^{20}$. Jednakże niektórzy urzędnicy, nawet $\mathrm{w}$ Białymstoku, jeszcze na wiosnę 1946 r. nie znali podstaw prawnych pobierania opłat przez kancelarie parafialne, co doprowadziło do nieporozumień z Kurią Metropolitalną Wileńską. Dopiero w maju 1946 r. sprawę tą wy jaśnił Urząd Wojewódzki Białostocki odpowiednio instruu jąc administrację niższych szczebli ${ }^{21}$.

Problemy z wdrażaniem dekretu znalazły swój wyraz w sprawozdaniu Oddziału Spraw Stanu Cywilnego i Ewidencji Ludności Urzędu Wojewódzkiego Białostockiego (OSSCiEL UWB) za okres od 1 maja do 30 września 1946 r.: „Urzędy stanu cywilnego na terenie województwa białostockiego, szczególnie na terenach będących w zasięgu działań band leśnych działają niezadawalająco ze względu na brak wykwalifikowanych sił na urzędników oraz brak uświadomienia wśród mieszkańców. Zacofane tradycje, brak odpowiedniej propagandy uświadamiającej, a co najważniejsze: wrogi stosunek proboszczów do nowego prawa, to najważniejsze trudności, z którymi

19 APwB, Urząd Wojewódzki Białostocki (dalej: UWB), syg. 41, Pismo wojewody białostockiego Stefana Dybowskiego do starostów powiatowych i prezydenta miasta Białegostoku z grudnia $1945 \mathrm{r}$.

20 Dziennik Ustaw Rzeczypospolitej Polskiej, Nr 48/1945, poz. 273, art. XIV, ust. 3. Opłaty ustalone rozporządzeniem z 24 listopada $1945 \mathrm{r}$. wynosiły: $5 \mathrm{zł}$ za wyciąg, 10 zł za odpis skrócony i 20 zł za odpis pełny (Dziennik Ustaw Rzeczypospolitej Polskiej, Nr 54/1945, poz. 304, § 109).

21 AKMB, Odpis pisma Wydziału Ogólnego UWB z 16 maja 1946 r. do Komendy III-go Oddziału S.K.P. w Białymstoku (wpłynął do Kurii Metropolitalnej Wileńskiej 21 maja 1946 r.). 
trzeba się liczyć jeszcze przez pewien czas" 22. Do zadrażnień z Kościołem przyczyniły się w znacznym stopniu - odnotowane w sprawozdaniu - naciski Urzędu Wojewódzkiego wywierane „na razie[!] w formie łagodnej” na księży proboszczów i Kurię Arcybiskupią w Białymstoku w celu zmniejszenia opłat kościelnych pobieranych od ludności. Np. wszczęto dochodzenie przeciwko proboszczowi parafii w Downarach, ks. Henrykowi Sobolewskiemu oskarżonemu o pobieranie wygórowanych stawek ${ }^{23}$. Zbieranie przez administrację skarg na księży antagonizowało duchowieństwo i wiernych oraz miało uzasadniać powstanie urzędów stanu cywilnego i laicyzację ślubów potrzebą odciążenia finansowego rzekomo wyzyskiwanych przez proboszczów parafian ${ }^{24}$.

Sprawozdanie informowało również, że Oddział Spraw Stanu Cywilnego ostateczne uregulowanie kwestii spornych z Kościołem postanowił odłożyć do wyborów do Sejmu Ustawodawczego, które odbyły się w styczniu 1947 r. ${ }^{25}$

Również sprawozdania za ostatnie trzy miesiące 1946 r. ujawniały niepowodzenia we wdrażaniu reformy zadekretowanej 25 września 1945 r. Kierownik OSSCiEL UWB, Kazimierz Chodorowski, przedstawiając sytuację w październiku, stwierdził: „Urzędy stanu cywilnego, jak wynika z materiału, uzyskanego w trakcie lustracyj, funkcjonuja na ogół słabo, a to na skutek nieprzyswojenia przez urzędników stanu cywilnego znajomości ustaw. Daje się odczuć brak odpowiednich kandydatów na urzędników. Najsprawniej działają urzędy: w Białymstoku i Suwałkach, lecz urzędy w gminach wiejskich nie spełniają należycie swego zadania" ${ }^{26}$. Także w sprawozdaniu za listopad i grudzień 1946 r. Chodorowski odnotował poważne trudności: „Z nadesłanych przez starostwa powiatowe protokołów lustracji urzędów stanu cywilnego wynika, że w powiatach Ziem Odzyskanych ${ }^{27}$ oraz północ-

22 APwB, UWB, syg. 40, Sprawozdanie Oddziału Spraw Stanu Cywilnego i Ewidencji Ludności ( dalej: OSSCiEL) UWB za okres od 1 maja do 30 września 1946 r.

23 Patrz przypis 21.

24 Naciski wywierane na duchowieństwo katolickie przez władze były jednocześnie elementem strategii odcinania tradycyjnych źródeł dochodów Kościoła, ułatwiać miały planowane finansowe uzależnienie go od państwa.

25 Patrz przypis 22. „Władzy ludowej” zależało na niezaostrzaniu w okresie kampanii przedwyborczej i tak już napiętych stosunków z Kościołem katolickim.

26 APwB, UWB, syg. 40, k. 7, Miesięczne sprawozdanie OSSCiEL UWB za październik 1946 r. sporządzone przez kierownika K. Chodorowskiego 5 listopada 1946 r.

27 Należy zauważyć, że urzędy stanu cywilnego i obowiązkowe śluby cywilne były nowością także dla zamieszkujących Ziemie Odzyskane repatriantów i migrantów z terenów, na których nie obowiązywało zlaicyzowane prawo małzeńskie. 
nej części województwa urzędy stanu cywilnego działają najsprawniej. Natomiast w zachodniej części województwa ludność odnosi się do tych spraw wręcz niechętnie. Wszędzie daje się odczuwać brak odpowiednich sił pracowniczych na stanowiska urzędników stanu cywilnego" 28.

Jeszcze przed wyborami, 5 grudnia 1946 r. w Urzędzie Wojewódzkim odbyło się spotkanie urzędników starostw zajmujących się lustracją urzędów stanu cywilnego w województwie białostockim z kierownikiem Oddziału Spraw Stanu Cywilnego. Lustratorzy stwierdzili, iż największe problemy $\mathrm{z}$ wdrażaniem nowego prawa o aktach stanu cywilnego napotkali w zachodnich powiatach województwa. Narzekali także na brak fachowych podręczników utrudniający szkolenie kandydatów na urzędników stanu cywilnego. Zresztą sami lustratorzy nie byli najlepiej zorientowani w przepisach, o czym świadczył szereg wątpliwości zgłoszonych w dyskusji nad referatem Chodorowskiego ${ }^{29}$.

Po wyborach styczniowych część mieszkańców województwa nadal bojkotowała urzędy stanu cywilnego, nie zgłaszając narodzin dzieci i biorąc ślub tylko w kościele. Jedynie $z$ rejestracją zgonów nie było poważniejszych trudności ${ }^{30}$. Jak wynika ze sprawozdania wojewody białostockiego za trzeci kwartał 1947 r. opór społeczeństwa najostrzejszy był w powiecie łomżyńskim, gdzie na terenie 8 gmin powstrzymywanie się ludności od dokonywania wpisów do akt stanu cywilnego miało charakter masowy, a w dwóch innych gminach akta zostały zniszczone przez niepodległościowy ruch oporu (podobny wypadek odnotowano w gminie Trzcianne powiatu białostockiego, sasiadującej z pow. łomżyńskim). W sprawozdaniu wojewody podkreślono, że perturbacje w działalności urzędów stanu cywilnego są spowodowane także brakiem „dostatecznej współpracy ze strony czynników wyznaniowych" 31 . Znamienne było to liczenie władz na współpracę Kościoła we wprowadzaniu „reformy” godzącej w religię i Kościół, świadczyło o arogancji i poczuciu siły.

28 APw B, UWB, syg. 40, k. 8, Sprawozdanie z działalności OSSCiEL UWB za listopad i grudzień 1946 r. sporządzone przez kierownika K. Chodorowskiego 9 stycznia 1947 r.

29 Nowe prawo o aktach stanu cywilnego musi znaleźć zrozumienie wszystkich obywateli, „Jedność Narodowa” nr 233 (324), 7 grudnia 1946, s. 3.

3060 tys. mieszkańców w Białymstoku. Praca Urzędu Stanu Cywilnego, „Życie Białostockie" nr 126 (969), 7 lipca 1947, s. 3. Niezgłoszenie zgonu groziło szybszymi i poważniejszymi konsekwencjami niż w przypadku niezarejestrowania narodzin lub ślubu.

31 APwB, UWB, syg. 83, Sprawozdanie z działalności wojewody białostockiego za III kwartał 1947 r., s. 6. 
W drugiej połowie 1947 r. Urząd Wojewódzki Białostocki wydał dyrektywy powiatowym władzom administracji ogólnej, by w każdym wypadku opóźnionego zgłoszenia urodzenia lub zgonu przeciwko winnym wdrożono dochodzenie karno-administracyjne ${ }^{32}$. Oprócz sankcji karnych opornym groziły inne prawne konsekwencje: w przypadku zawarcia ślubu tylko w kościele małżonkowie nie mogli po sobie dziedziczyć, żona nie miała prawa do nazwiska męża, a dzieci traktowano jak nieślubne; w przypadku niezgłoszenia urodzin dziecko nie otrzymywało kart żywnościowych, a dorastając narażone było na kłopoty w związku z koniecznością nauki szkolnej i obowiązkiem służby wojskowej33. Mimo dolegliwości kar, jeszcze w roku 1948 nie wszyscy mieszkańcy woj. białostockiego respektowali (i prawdopodobnie nie wszyscy znali) obowiązki narzucone dekretem z 25 września 1945 r. Władze wciąż musiały prowadzić akcję informacyjną na temat świeckiego prawa małżeńskiego ${ }^{34}$.

W latach 1947-1948 utrzymywało się napięcie między władzami a duchowieństwem katolickim w województwie na tle desakralizacji instytucji małżeństwa, wprowadzenia świeckiej rejestracji urodzeń i zgonów oraz związanej z tym kampanii oszczerstw pod adresem Kościoła. Już samo podważanie nierozerwalności katolickiego małżeństwa stawiało księży na pozycji przeciwników obozu rządzącego. Oliwy do ognia dolewało pomawianie duchowieństwa o to, że sprzeciwia się nowemu prawu nie ze względów dogmatycznych, ale ponieważ obawia się utraty dochodów z opłat kancelaryjnych. Ponadto zadrażnienia powodowane były roszczeniem sobie praw przez urzędy stanu cywilnego do nieograniczonego korzystania z metryk kościelnych.

W przywoływanym już sprawozdaniu wojewody białostockiego z $1947 \mathrm{r}$. odnotowano, że kancelarie parafialne „[...] w znaczącej liczbie wypadków nie udzielały odpowiedzi informującej o dokonaniu przypisków wzgl. [względnie] podpisków, co z kolei wywoływało ze strony urzędników stanu cywilnego zakazy wydawania odpisów oraz powodowało korespondencję z władzami diecezjalnymi" ${ }^{35}$. Dekret powołujący urzędy stanu cywilnego, funkcjonujące od

32 Ibidem.

33 Niedbalstwo i nawyki okupacyjne, „Życie Białostockie” nr 202 (1045), 21 września 1945 , s. 2.

$34 \mathrm{~W}$ dziedzinie popularyzacji prawa osiagnęliśmy najlepsze wyniki, „Życie Białostockie" nr 75 (1217), 16 marca 1948, s. 3. Działalność białostockiej Komisji Popularyzacji Prawa nadal była zdominowana przez tematykę małżeńską.

35 Patrz: przypis 31. 
1 stycznia 1946 r., co prawda zobowiązywał księży do udzielania urzędnikom świeckim wglądu do metryk powstałych przed tą datą, jednak niejednokrotnie urzędnicy żądali udostępnienia im wpisów metrykalnych powstałych już w czasie obowiązywania nowego prawa, tzn. w okresie, w którym metryki stały się wyłącznie dokumentami wewnątrzkościelnymi. Sprawą udostępniania urzędom państwowym ksiąg metrykalnych zajęła się 7 lipca $1948 \mathrm{r}$. kongregacja księży dziekanów diecezji łomżyńskiej, na której obecni byli m.in. ordynariusz łomżyński bp Stanisław K. Łukomski i sufragan bp Paweł Z. Rydzewski. W komunikacie ze spotkania ogłoszonym w „Rozporządzeniach Urzędowych Łomżyńskiej Kurii Diecezjalnej" wyrażono stanowisko strony kościelnej: „Tylko za okres do 1 stycznia 1946 r. Księża Proboszczowie nadal są uważani za prowadzących akta Stanu Cywilnego i z tego czasu obowiązani są do wydawania druczków metrycznych i wszelkich wykazów, jak dotąd, władzom, według praktyki przedwojennej" ${ }^{36}$. Kongregacja, być może obawiając się konfiskaty ksiąg metrykalnych przez władze, poleciła proboszczom sporządzić duplikaty aktów metrykalnych powstałych od początku 1946 r. oraz tworzonych na bieżąco, i dostarczyć je do kurii ${ }^{37}$.

Jesienią 1948 r. Urząd Wojewódzki Białostocki pismem z 29 listopada zwrócił się do Kurii Metropolitalnej Wileńskiej o zezwolenie na sporządzanie wtóropisów z ksiąg metrykalnych znajdujących się w dyspozycji księży proboszczów archidiecezji. Kuria zgodziła się na korzystanie z dokumentów kościelnych przez urzędników stanu cywilnego wydelegowanych przez UWB "[...] z tym jednak zastrzeżeniem, by księgi te nie były wynoszone $\mathrm{z}$ kancelarii parafialnych i by nie zostały one uszkodzone" 38 .

W trakcie kongregacji łomżyńskiej poruszono również temat zarzucania Kościołowi przez komunistyczną propagandę pobierania wygórowanych opłat za chrzty, śluby i pogrzeby. Księża dziekani, chcąc uniknąć sytuacji, w której oskarżenia propagandy reżimowej znalazłyby potwierdzenie w oczach parafian, apelowali do księży proboszczów: „Z uwagi na dzisiejsze stosunki gospodarczo-społeczne opłaty kancelaryjne i za posługi religijne powinny być bardzo umiarkowane" ${ }^{39}$. Stosowana w kampanii promującej

36 Kongregacja K'sięzy Dziekanów, odbyta w sali Seminarium Duchownego w Eomży w dniu 7 lipca 1948 r., „Rozporządzenia Urzędowe Łomżyńskiej Kurii Diecezjalnej” nr 7-9, 31 lipca 1948 , s. 92.

37 Ibidem, s. 91-93.

38 AKMB, Pismo okólne Kanclerza Kurii Metropolitalnej Wileńskiej do księży dziekanów archidiecezji z 29 listopada $1948 \mathrm{r}$.

39 Kongregacja Księży Dziekanów..., s. 91. 
świeckie śluby i urzędy stanu cywilnego metoda pomawiania duchowieństwa o kierowanie się pobudkami natury finansowej okazała się w pewnym sensie bronią obosieczną. W grudniu $1948 \mathrm{r}$., w atmosferze zaostrzającej się walki z religią i Kościołem, rozeszła się w województwie białostockim pogłoska (zdaniem władz rozpowszechniana przez księży), jakoby od nowego roku (1949) rząd miał wyznaczyć wysokie opłaty za sakramentalne śluby, chrzty i pogrzeby w celu odstraszenia ludzi od ceremonii religijnych ${ }^{40}$.

W pierwszych latach działalności urzędów stanu cywilnego i obowiązywania zlaicyzowanego prawa małżeńskiego propaganda komunistyczna w województwie podejmowała działania mające oswoić obywateli ze zmianami i wprowadzić nowe świeckie obyczaje, konkurujące ze „starymi” obrzędami religijnymi. Zajmowało się tym kilka instytucji: Wojewódzki Urząd Informacji i Propagandy, Oddział Spraw Stanu Cywilnego i Ewidencji Ludności Urzędu Wojewódzkiego, Komisja Popularyzacji Prawa i Wydział Propagandy KW PPR ${ }^{41}$.

Specjalne znaczenie władze przywiązywały do propagowania zawierania związków małżeńskich przed urzędnikiem stanu cywilnego. W styczniu i lutym 1946 r. organ prasowy WUIiP („Jedność Narodowa”) informował o pierwszych ślubach cywilnych w Białymstoku i Łomży ${ }^{42}$. Szczególny wydźwięk miał związek zawarty w Łomży, gdyż młoda para otrzymała od Wydziału Mieszkaniowego Zarządu Miejskiego jako podarunek ślubny mieszkanie $^{43}$. W roku 1946 kampania popularyzująca nowe prawo małżeńskie była łączona $z$ agitacją polityczną przed referendum czerwcowym i wyborami styczniowymi (1947 r.). W czerwcu w świetlicach WUIiP odbywały się wykłady łączące tematykę referendum i świeckiego prawa małżeńskiego ${ }^{44}$. $\mathrm{Z}$ kolei w programie wojewódzkiego kursu agitatorów i organizatorów przedwyborczych znalazło się zalecenie, aby propagandziści w swojej pracy przed

40 APwB, Komitet Wojewódzki PZPR (dalej: KW PZPR), syg. 33/VI/5, Sprawozdanie miesięczne KW PZPR w Białymstoku za grudzień 1948 r. s. 3; APwB, KW PZPR, syg. 33/V/11, Raport specjalny szefa Wojewódzkiego Urzędu Bezpieczeństwa Publicznego w Białymstoku mjr Szysza dla KW PZPR w Białymstoku z 8 stycznia 1949 r.

41 Zadania propagandowe wypełniali również urzędnicy stanu cywilnego - patrz przypis 22 .

42 Pierwszy ślub cywilny w Białymstoku, „Jedność Narodowa” nr 4 (95), 9-10 stycznia 1946, s. 4; Pierwszy ślub cywilny, „Jedność Narodowa” nr 15 (106), 3-5 lutego 1946, s. 6 .

43 Warto zauważyć, że był to charakterystyczny przykład rozdawnictwa publicznego majątku z klucza ideologicznego.

44 APwB, WUIiP, syg. 7, Miesięczne sprawozdanie Referatu Świetlicowego WUIiP w Białymstoku za czerwiec 1946 r., s. 1. 
wyborami zwalczali przy okazji pogląd głoszący, że „śluby cywilne i ustawy o rozwodach wprowadzaja demoralizacje" ${ }^{45}$. Co najmniej od jesieni 1946 r., w akcję informacyjną o świeckim prawie małżeńskim włączyła się Komisja Popularyzacji Prawa. Szczególnie intensywnie pracowała ona we wrześniu, kiedy to prelegenci komisji w urzędach i instytucjach państwowych wygłaszali referat pt. Paragraf rozwodu w obecnym prawie matżeńskim, a w każdą środę radiowęzeł białostocki nadawał w cyklu „Poznajmy prawo” pogadanki wiceprezesa Sądu Okręgowego w Białymstoku Józefa Sawciłło o zmianach w prawie małżeńskim ${ }^{46}$. Jeszcze w 1948 r. lwią część działalności Komisji Popularyzacji Prawa stanowiło promowanie świeckiego prawa małżeńskiego ${ }^{47}$. Powstałe w marcu 1947 r. "Życie Białostockie” cyklicznie drukowało dane statystyczne podawane przez Urząd Stanu Cywilnego w Białymstoku, np. w październiku 1947 r. z pompa poinformowało o tysięcznych narodzinach zarejestrowanych przez urząd ${ }^{48}$.

Wprowadzona dekretem z 25 września 1945 r. obowiązkowa rejestracja urodzin, związków małżeńskich i zgonów miała charakter biurokratycznej formalności i w przeciwieństwie do religijnych ceremonii chrztu, sakramentu małżeństwa i pogrzebu, nie była świętem w życiu katolickiej społeczności. Komuniści, chcąc, aby świecka rejestracja w życiu zwykłych obywateli dorównała znaczeniem ceremoniom kościelnym (a z czasem je zdominowała i wyparła), starali się nadać uroczystą (naśladującą sakralną) oprawę formalnościom w urzędach stanu cywilnego. W latach 1946-1948 uwidoczniło to się przede wszystkim w przypadku procedury zgłaszania urodzeń.

Próby wprowadzenia do świadomości społecznej pojęcia „chrztu cywilnego" były charakterystycznym przykładem laicyzacyjnych dążeń komunistów. Świecka ceremonia polegająca na sporządzeniu aktu urodzenia upodobniana była do sakramentu kościelnego: rolę kapłana pełnił urzędnik stanu cywilnego, obecni byli świeccy „rodzice chrzestni”, których nazwiska wpisywano do ksiąg metrykalnych, a treścią obrzędu było wprowadzenie dziecka do grona obywateli (podczas gdy sakrament chrztu wprowadzał

45 APwB, KW PPR, syg. 1/VI/14, Projekt programu 3-tygodniowego wojewódzkiego kursu agitatorów i organizatorów przedwyborczych z 1946 r., s. 2.

46 APwB, WUIiP, syg. 8, Sprawozdanie miesięczne Referatu Szkoleniowego WUIiP w Białymstoku za wrzesień 1946 r., s. 2-3.

47 Patrz: przypis 34.

48 Tysięczne urodziny $w$ Urzędzie Stanu Cywilnego, „Życie Białostockie” nr 234 (1077), 23 października 1947, s. 3. Chwalenie się „osiągnięciami” urzędów stanu cywilnego przychodziło tym łatwiej, że nie podawano do publicznej wiadomości kosztów ich utworzenia i funkcjonowania. 
do Kościoła). Pierwszy „chrzest cywilny” w Białymstoku (braci bliźniaków Bolesława i Konstantego G.) odbył się we wrześniu 1946 r. i był szeroko opisywany w dwukrotnie drukowanym artykule „Jedności Narodowej” 49. "Ojcami chrzestnymi" zostali prezydent KRN Bolesław Bierut (nieobecny na uroczystości) i prezydent Białegostoku Andrzej Krzewniak. W ceremonii odbywającej się w gabinecie prezydenta miasta uczestniczyły - tak jak w kościele - dzieci trzymane przez świeckie „matki chrzestne”. Później (w latach 1947-1948) prasa białostocka jeszcze niejednokrotnie donosiła o przyjmowaniu przez Bieruta roli „ojca chrzestnego", który jednak na „chrzcinach" nigdy się nie pojawiał, powierzając zwykle zastępstwo lokalnym starostom ${ }^{50}$. Co ciekawe, zdarzało się, że reprezentant prezydenta trzymał dziecko do chrztu także w kościele ${ }^{51}$.

Jakie były prawdziwe motywy wydania dekretu z 25 września 1945 r.? Jako nieszczere można potraktować uzasadnienia w rodzaju: chęci poszerzania obywatelskich wolności, ochrony przed wyzyskiem duchownych, czy nadążania za „dorobkiem kultury prawnej suwerennych państw cywilizowanych" ${ }^{2}$. Natomiast ujawniane dążenie do ujednolicenia systemu prawnego, choć było jednym $\mathrm{z}$ prawdziwych motywów, to $\mathrm{z}$ pewnością nie najważniejszym - wbrew niektórym twierdzeniom propagandy. $\mathrm{W}$ wejrzeniu $\mathrm{w}$ decydujące, a skrywane motywy decydentów pomóc może przeanalizowanie konsekwencji nowego prawa.

Następstwa dekretu z 25 września 1945 r. były wielostronne: prawne, prawno-etyczne, obyczajowe, finansowe, społeczno-polityczne, ustrojowe. Dotykały one wszystkich: narzeczonych, małżonków, rodziców, rodziny zmarłych i nawet osoby samotne, bo każdy musiał znaleźć się w ewidencji ưrzędów stanu cywilnego.

Już same konsekwencje prawne były rozległe. Pluralistyczne prawo małżeńskie, szanu jące odmienności religijne, respektujące wielokulturowość Polski, zastąpiono prawem „świeckim" reprezentującym punkt widzenia (i interesy) osób ży jących.zgodnie ze światopoglądem materialistycznym (m.in. ludzi niewierzących i tzw. „katolików wierzących ale nie praktykujących”).

49 Dwaj bracia bliźniaczy, Bolestaw i Konstanty Grygorczukowie pierwszymi synami chrzestnymi Prezydenta Bieruta w ziemi Białostockiej, „Jedność Narodowa” nr 158 (249) z 8 września 1946 r. oraz nr 159 (250) z 10 września 1946 r.

50 „Życie Białostockie” 1947, nr 170 (1013), 207 (1050), 213 (1056); 1948, nr 34 (1176), 42 (1184), 58 (1200), 68 (1210), 95 (1237), 130 (1272), 154 (1296).

51 „Życie Białostockie” nr 34 (1176) z 4 lutego 1948 r.

52 Patrz przypis 5. 
Zatem prawo zostało dostosowane do zapatrywań mniejszości, kosztem większości. Na wszystkich obywateli nałożono obowiązek urzędowej rejestracji urodzeń, zgonów, związków małżeńskich. Zlikwidowano pożyteczną instytucję separacji małżeńskiej ${ }^{53}$, którą zastąpiono rozwodami dla wszystkich (przez pierwsze trzy lata na żądanie). Władze państwowe przestały respektować jurysdykcję sądów kościelnych w sprawach małżeńskich (sprawy te zostały przekazane sądom państwowym $)^{54}$. Szczególnie przykre konsekwencje poniosły osoby, które nie wypełniały nowych obowiązków narzuconych społeczeństwu dekretem.

Mniej dostrzegalne, bo długofalowe efekty natury moralno-obyczajowej były rezultatem rozejścia się prawa i etyki uznawanej przez większość społeczeństwa (tzn. katolików). Możliwość rozwodów oferowana przez prawo państwowe także dla członków wspólnot religijnych uznających nierozerwalność małżeństwa zachęcała do łamania zasad religijnych. Konflikt między prawem stanowionym a zasadami religijnymi musiał powodować osłabienie poszanowania przepisów prawnych lub religijnych, albo nawet jednych i drugich. Intensywna propaganda rozwodów (które rzekomo miały być panaceum na bolączki rodzinne) przełamywała powoli, ale systematycznie barierę psychiczną chroniącą nierozerwalność małżeństwa i (w efekcie) małżeńską wierność. Sprzężone z laicyzacją rozluźnianie obyczajów, osłabiając morale wiernych - osłabiało Kościół i czyniło społeczeństwo podatniejszym na oddziaływanie socjotechniczne.

Dekret wrześniowy pociągnął za sobą również skutki finansowe. Na całe społeczeństwo zostały rozłożone koszty powstania i funkcjonowania urzędów stanu cywilnego na tych terenach, gdzie przed 1 stycznia 1946 r. były niepotrzebne. Osoby, które wcześniej urodziny i zgony zgłaszały, a śluby zawierały tylko w kościele zostały obciążone dodatkowymi opłatami przy rejestracji cywilnej (kto chciał zaoszczędzić i nie ponieść konsekwencji prawnych mógł to uczynić jedynie kosztem zaniedbania obowiązków religijnych). Zmniejszyły się dochody Kościoła, na co wpływało zarówno samoograniczanie się, jak i naciski ze strony władz świeckich. Państwo otrzymało do obrotu dodatkowe środki pieniężne, co jednak wcale nie oznaczało przysporzenia dochodu

$53 \mathrm{Na}$ likwidacji separacji stracili wszyscy: osoby nie uznające trwałości małżeństwa pozbawiono wyboru między rozwodem a separacją; natomiast małżonków nie uznających rozwodów, w sytuacji kiedy nie mogli ze sobą wytrzymać, zmuszono albo do wspólnego życia albo do rozwodu wbrew przekonaniom.

54 Np. nie uznawano unieważnienia małżenstwa orzeczonego przez Kościół, wymagając rozwodu cywilnego. 
- bo jeśli przychód (czyli wpływy z opłat) był mniejszy niż koszty wprowadzenia i utrzymywania urzędów stanu cywilnego (tam gdzie ich wcześniej nie było), to cała reforma przyniosła finansom publicznym straty.

Kolejną konsekwencją był rozrost administracji w terenie - dotyczyło to głównie pracowników urzędów stanu cywilnego oraz odpowiednich komórek w strukturze urzędów wojewódzkich.

Wreszcie dekret zwiększył uprawnienia państwa wobec mieszkańców. Przejęcie pełnej kontroli nad rejestracją ruchu ludności było naturalnym posunięciem władz: dążących do omnipotencji państwa (gdyż zwiększało kontrolę nad wszystkimi i każdym z osobna), budu jących państwo policyjne (w społeczeństwie policzonym i zewidencjonowanym trudniej się ukryć przed bezpieką), stosu jących inżynierię społeczną (gospodarowanie zasobami ludzkimi jest łatwiejsze, gdy ma się je zlustrowane). Ograniczona została wolność obywatelska w kwestii wyboru sposobu zawarcia małżeństwa oraz zawężono uprawnienia obywateli przez likwidację instytucji separacji małżeńskiej.

Można uznać, że władze były w stanie przewidzieć wszystkie skutki swojego posunięcia i jeśli nie wycofały się z niego mimo protestów Kościoła, niechęci ludności i nieprzygotowania administracji terenowej, to znaczy, że na skutki te rządzący się godzili i na większości z nich - jeśli nie na wszystkich - im zależało. Wiele wskazuje na to, że obok osłabienia Kościoła, podstawowym celem dekretu wrześniowego było zwiększenie kontroli nad społeczeństwem (i wiedzy o nim) poprzez ustanowienie pełnej kontroli władz państwowych nad ewidencją ruchu ludności.

Upowszechnienie świeckiego prawa małżeńskiego i urzędów stanu cywilnego przy sprzeciwie Kościoła i braku akceptacji ze strony katolickiej społeczności było charakterystycznym przykładem stosowanej przez „władzę ludową" polityki faktów dokonanych. Ingerencja obozu rządzącego w sferę moralno-obyczajową świadczyła o totalitarnych zapędach, była też zapowiedzią ofensywy ideologicznej lat następnych. 